Arab Univ. J. Agric. Sci., Ain Shams Univ., Cairo, 13(3), 863-875, 2005

\title{
INTERACTIVE EFFECTS OF ZINC AND DIFFERENT NITROGEN SOURCES ON YIELD AND QUALITY OF ONION [57]
}

\author{
Abdel-Mawgoud', A.M.R.; S.D. Abou-Hussein'1; S.R. Salman' \\ and M.A. El-Nemr ${ }^{1}$
}

\begin{abstract}
This study was conducted on a sandy loamy soil at Giza, Egypt, in December 2002 and 2003 to investigate the interactive effect of $\mathrm{Zn}$ and different nitrogen sources, i.e., mineral nitrogen (ammonium sulfate) and organic nitrogen (poultry manure) on the growth and productivity of onion (Allium cepa) cv. Giza 20. Four levels of $\mathrm{Zn}$ application $(0,1,2$ and $3 \mathrm{ppm})$ in a sulfate form were foliar sprayed at 30 and 60 days after planting. Within each $\mathrm{Zn}$ application, three treatments of nitrogen dose were applied in different combination forms (mineral and organic sources). Nitrogen treatments were $100 \%$ mineral N; $75 \%$ mineral $+25 \%$ organic and $50 \%$ mineral $+50 \%$ organic. Organic-N source was poultry manure. All poultry manure treatments were applied during soil preparation. Data showed that all growth parameters of onion plants increased as the fraction of poultry manure increased. $\mathrm{Zn}$ had also a positive effect on all plant parameters except of plant length, and leaf dry weight. The interactive effect of $\mathrm{Zn}$ and poultry manure increased yield and quality of onion bulbs. The most effective treatments on bulb fresh weight, total yield and quality were the spraying with 1 or 2 ppm zinc and the application of $\mathrm{N}$ as $75 \%$ mineral and $25 \%$ organic, in both seasons.
\end{abstract}

Keywords: Allium cepa, Onion, Poultry manure, Zn, N-sources

\section{INTRODUCTION}

The demand for onion crop is growing worldwide with a trading amount reaching up to 4,788,235 tones having a value of 1,331 billion US-dollars of which Egypt exported 32 thousand tones with a value of 33 million USdollars (FAO, 2004). Because of this importance, expansion of onion cultivation is taking place in the new reclaimed lands in Egypt. However, reclaimed lands have many problems such as poor structure and nutrient deficiency in particular micronutrients. Zinc is a very important micronutrient, which plays important roles in creation of many enzymes in plants that are responsible for driving many metabolic reactions in the synthesis of proteins. Growth and development would stop if these specific enzymes were not present in plant tissue (Joiner, 1983; Jones, 1983; Resh, 1983 and Bergman, 1985). Effect of different application methods of $\mathrm{Zn}$ on onion crop was

1- Vegetable Research Department, National Research Center, Dokki, Cairo, Egypt

(Received April 19, 2005)

(Accepted May 16, 2005) 
Arab Univ. J. Agric. Sci., Ain Shams Univ., Cairo, 13(3), 863-875, 2005

previously reported (Weaver, 1985;

Khan and Weaver, 1989). Although absorption of $\mathrm{Zn}$ from nutrient solution was more efficient than from soil (Weaver, 1985), foliar application of Zn was even more effective than application to the root environment (Khan and Weaver, 1989).

The effect of $\mathrm{Zn}$ on growth and yield of onion has been widely investigated. Sprays of $\mathrm{Zn}$ were effective for increasing all the growth parameters of onion (Singh \& Tiwari, 1995 and Kumar et al 1998 \& 2000). Also, yield of onion responded positively to foliar sprays with $\mathrm{ZnSO}_{4}$ (Brouwer et al 1981; Gupta, 1991; Pena et al 1999; Sliman et al 1999 and Kumar et al 1998 \& 2000).

Improving growth and productivity of onion in the newly reclaimed lands may be achieved by applying organic matter to the soil. The positive effects of organic matter on production have been extensively investigated (Giardini et al 1992; Kropisz, 1992 and Vinay et al 1995). More recently, Gupta et al (1999) and Abbey (2000) revealed that organic manure along with mineral fertilizers were effective in increasing the growth, yield and quality contributing characters. Poultry manure has long been recognized as the most desirable of natural fertilizers because of its high nitrogen content and other essential plant nutrients and serve as a soil amendment by adding organic matter (Sloan et al 1996).

The effect of soil organic matter content on the availability of $\mathrm{Zn}$ has been discussed in the literature. Soil organic matter amendments influence the availability of micronutrients to plants by forming fulvic acid during decomposition. By complexation with fulvic acid, $\mathrm{Zn}$ availability may be increased in soils under aerated conditions (Tagwira et al 1992).

Recent research on sandy soils indicates that the response to $\mathrm{Zn}$ can occur when high yields are grown on sandy soils with a low organic matter content (Rehm and Schmitt, 2000).

Therefore the aim of this study was to investigate the interactive effect of different levels of poultry manure and foliar zinc applications on the growth and productivity of onion.

\section{MATERIAL AND METHODS}

This study was conducted on a sandy clay loam soil at Kafr Hakim village, Giza, Egypt in December 2002 and 2003. Soil sample was collected from surface $20 \mathrm{~cm}$ layer. The soil was airdried, and sieved through $2 \mathrm{~mm}$ sieve .The main physical and chemical properties are shown in Table 1 ( $a$ and $b$ ). Each experimental plot was $4 \times 6$ m contained 10 rows each of $4 \mathrm{~m}$ long and $50 \mathrm{~cm}$ width. The outside rows of each plot were considered as boarders. The center two rows of each plot were used for plant sampling. Onion (Allium cepa) cv. Giza 20 was transplanted on both sides of rows at $7-8 \mathrm{~cm}$ with in-row $\left(38\right.$ plant $\left.\mathrm{m}^{-2}\right)$ in December 2002 and 2003. Onion was surface-irrigated during the growing season.

1- Vegetable Research Department, National Research Center, Dokki, Cairo, Egypt 
Effect of zinc and nitrogen on onion

Four levels of $\mathrm{Zn}$ application $(0,1,2$ and $3 \mathrm{ppm}$ ) in a sulfate form were foliary sprayed. The foliar applications were carried out at 30 and 60 days after transplanting. Within each $\mathrm{Zn}$ treatment, three poultry fertilizer rates $(0.0,15.0$ and
$30.0 \mathrm{~m}^{3} \mathrm{ha}^{-1}$ ) were established. The analysis of the used poultry manure in this experiment is shown in Table 1 (c). The total dose of applied nitrogen was the same for all treatments and as recommended by the ministry of 
Arab Univ. J. Agric. Sci., Ain Shams Univ., Cairo, 13(3), 863-875, 2005

Table 1a. Saturation percentage, particle size distribution, textural class,organic matter, and calcium carbonate percentage of the studied soil profile collected from Kafr Hakim .

\begin{tabular}{|ccccccccc|}
\hline $\begin{array}{c}\text { Depth } \\
(\mathrm{cm})\end{array}$ & \multicolumn{3}{c}{ Particle size distribution (\%) } & & $\begin{array}{c}\text { Textural } \\
\text { Class }\end{array}$ & $\begin{array}{c}\text { O.M } \\
\%\end{array}$ & $\mathrm{CaCO}_{3} \%$ \\
\cline { 2 - 5 } & $\begin{array}{c}\text { Coarse } \\
\text { sand }\end{array}$ & $\begin{array}{c}\text { Fine } \\
\text { sand }\end{array}$ & Silt & Clay & & & \\
\hline $0---20$ & 19.4 & 39.8 & 8.00 & 32.8 & Sandy clay loam & 1.7 & 2.3 \\
$20--40$ & 41.7 & 43.6 & 6.7 & 8.00 & Loamy sand & 0.6 & 1.2 \\
\hline
\end{tabular}

Table 1b. chemical analysis of the studied soil profile collected from Kafr Hakim

\begin{tabular}{|c|c|c|c|c|c|c|c|c|c|c|c|}
\hline \multirow{2}{*}{$\frac{\text { Sample }}{\text { No. }}$} & \multirow{2}{*}{$\begin{array}{c}\text { Depth } \\
(\mathrm{cm})\end{array}$} & \multirow[t]{2}{*}{$\mathrm{pH}$} & \multirow{2}{*}{$\begin{array}{c}\text { EC } \\
\mathrm{ds} / \mathrm{m}\end{array}$} & \multicolumn{4}{|c|}{ Soluble cations (meq/L) } & \multicolumn{4}{|c|}{ Soluble anions $(\mathrm{meq} / \mathrm{L})$} \\
\hline & & & & $\mathrm{Ca}^{++}$ & $\mathrm{Mg}^{++}$ & $\mathrm{Na}^{+}$ & $\mathrm{K}^{+}$ & $\mathrm{CO}_{3}=$ & $\mathrm{HCO}_{3}^{-}$ & $\mathrm{Cl}^{-}$ & $\mathrm{SO}_{4}=$ \\
\hline 1 & $00-20$ & 7.11 & 1.4 & 3.7 & 2.8 & 7.4 & 0.1 & --- & 4.1 & 5.8 & 4.1 \\
\hline 2 & $20-40$ & 7.23 & 0.93 & 2.7 & 1.3 & 5.2 & 0.1 & ---- & 3.6 & 4.0 & 1.7 \\
\hline
\end{tabular}

Table (1c) Chemical analysis of poultry manure.

\begin{tabular}{|cccccccccccc|}
\hline $\mathrm{p} \mathrm{H}$ & $\begin{array}{c}\mathrm{O} . \mathrm{M} \\
\%\end{array}$ & $\begin{array}{c}\mathrm{C} \\
\%\end{array}$ & $\begin{array}{c}\mathrm{N} \\
\%\end{array}$ & $\begin{array}{c}\mathrm{P} \\
\%\end{array}$ & $\mathrm{~K} \%$ & $\mathrm{Ca} \%$ & $\begin{array}{c}\mathrm{Mg} \\
\%\end{array}$ & $\begin{array}{c}\mathrm{Na} \\
\%\end{array}$ & $\begin{array}{c}\mathrm{Fe} \\
\%\end{array}$ & $\begin{array}{c}\mathrm{Zn} \\
(\mathrm{ppm})\end{array}$ & $\begin{array}{c}\mathrm{Cu} \\
\mathrm{pp} \\
\mathrm{m}\end{array}$ \\
\hline 7.5 & 45.6 & $\begin{array}{c}36 . \\
9\end{array}$ & 3.1 & 0.183 & 2.25 & 1.19 & 0.52 & 0.32 & 0.13 & 523 & 387 \\
\hline
\end{tabular}

Agriculture in Egypt (250 Kg N/ha.). However, this rate of nitrogen was established from the organic and mineral sources according to the experimental treatments, which were as follows:

$1.100 \%$ mineral nitrogen (Recommended dose) as control.
$2.75 \%$ mineral $\mathrm{N}$ dose $+25 \%$ Equivalent organic nitrogen $\left(15 \mathrm{~m}^{3}\right.$ poultry manure)

3. $50 \%$ mineral $\mathrm{N}$ dose $+50 \%$ Equivalent organic nitrogen $\left(30 \mathrm{~m}^{3}\right.$ poultry manure)

All the calculated amounts of poultry manure were applied during soil preparation. The mineral nitrogen

1- Vegetable Research Department, National Research Center, Dokki, Cairo, Egypt 
Arab Univ. J. Agric. Sci., Ain Shams Univ., Cairo, 13(3), 863-875, 2005

fertilizer dose was split and applied to the soil 30 and 70 days after transplanting. Cultural operations other than experimental treatments were carried out according to the recommendations of Extension Services Department, Ministry of Agriculture, Egypt.

Plant lengths, number of leaves, fresh and dry weights of leaves were recorded at 80 days after planting. Onion samples were collected at harvest time, i.e., two rows, $2 \mathrm{~m}$ long, was harvested from each plot where, bulb diameter and thickness of neck were determined. The onion bulbs were weighted to determine fresh weight then dried at $60^{\circ} \mathrm{C}$ to determine DM content. Total yield were recorded and calculated as (ton/ha).

Chemical analysis of nitrogen and zinc in plant leaves ( 80 days after transplanting) was determined according to Black (1965) and Chapman and Pratt (1961) respectively.

A split plot design was used and the analysis of variance procedures were conducted using SAS statistical procedures (SAS Inst., 1991). All differences discussed are significant at the $P 0.05$ probability level unless otherwise stated. LSD was calculated only when the analysis-of-variance $F$-test was significant at the $P 0.05$ probability level. Linear regression analyses using data of the two seasons were carried out in order to find any possible correlation between different experimental factors and recorded parameters.

\section{RESULTS}

\section{Vegetative growth}

\section{Effect of Zn foliar application}

Plant length did not show any significant difference in response to $\mathrm{Zn}$ application Table 2 ( $a$ and $b$ ). The regression analysis showed also no correlation to $\mathrm{Zn}$ application (Table 3). The effect was more pronounced on leaf number, which showed a significant increment in response to all $\mathrm{Zn}$ applications compared to control. The response rate was also clear to the application rate of $\mathrm{Zn}$. Leaf fresh weight responded positively to $\mathrm{Zn}$ application up to $2.0 \mathrm{ppm}$. However, application of $\mathrm{Zn}$ in concentration of $3.0 \mathrm{ppm}$ was not significantly different than control. On the other hand, leaf dry weight was not significantly different in all $\mathrm{Zn}$ treatments.

\section{Effect of poultry manure}

Onion plants responded to nitrogen source treatments added in the form of poultry manure as shown in Tables ( $2 \mathrm{a}$ and $b$ ). There was a linear and significant increment in plant length in response to increasing the fraction of organic nitrogen source. The rate of response expressed as the slope of regression line, was very related to the amount of poultry manure applied to the crop $\left(\mathrm{R}^{2}=0.86\right)$ (Table 3$)$. Number of leaves per plant showed similar positive trend to the amount of poultry manure applied with high correlation however in a slower rate. Leaf fresh weight increased significantly in

1- Vegetable Research Department, National Research Center, Dokki, Cairo, Egypt 
response to poultry manure application compared to control treatment. However, plants receiving low poultry manure were significantly lower than those receiving high poultry manure. Linear regression showed a fair relationship $\left(\mathrm{R}^{2}=0.55\right)$ between leaf fresh weight and poultry manure application. Leaf dry weight showed a very clear significant response to poultry manure treatments with a very strong correlation however the rate of response was very low.

\section{Interaction effect of poultry manure and Foliar $\mathrm{Zn}$ applications}

Plant length responded positively to the interaction effect of poultry manure and $\mathrm{Zn}$ rate applications as shown in Tables ( $2 \mathrm{a}$ and b). Zn foliar application at 1.0 -ppm concentration with the highest amount of poultry manure showed the highest effect on plant length compared to control. All combinations ( $\mathrm{Zn}+$ poultry manure) of treatments significantly increased number of leaves per plant. Leaf fresh weight significantly increased in response to the interactive effect of the two experimental factors with exception of high poultry manure with null $\mathrm{Zn}$ and null poultry manure with $1 \mathrm{ppm} \mathrm{Zn}$ treatments. Only in the first season, treatment of null poultry manure with 3 ppm $\mathrm{Zn}$ application was significantly lower than control. Leaf dry weight responded differently where the highest responses were recorded with the low and high poultry manure additions associated with 1, 2 and 3 ppm Zn foliar applications and were significantly higher than control.

\section{Yield}

\section{Effect of Zn foliar application}

Effect of $\mathrm{Zn}$ application on individual bulb fresh weight was positive compared to control (0.0 ppm Zn), Table (2 a and b). This was reflected on total yield, which is a function of individual bulb fresh weight and number of plants per hectare. Bulb dry weight responded positively to $\mathrm{Zn}$ application however, the response to $3 \mathrm{ppm}$ application was smaller compared to 1 and 2 ppm application but still significant than control treatment. No linear relationship could be found between the applied concentrations of $\mathrm{Zn}$ and any of bulb fresh and dry weights and total yield.

\section{Effect of poultry manure}

Table ( $2 \mathrm{a}$ and $\mathrm{b})$ shows that addition of low $(25 \%)$ or high $(50 \%)$ poultry manure amounts positively influenced bulb fresh weight compared to null addition. Low poultry manure treatment was significantly higher than high poultry manure treatment. Bulb dry weight showed the same positive response to the addition of poultry manure however this response was linear with rates of poultry manure addition (Table 3 ). Total yield was a reflection of individual bulb fresh weight and showed a similar response.

\section{Effect of interaction of poultry manure and $\mathrm{Zn}$ applications}

With no exception all combinations of poultry manure and $\mathrm{Zn}$ application treatments showed a positive and significant effect on fresh weight of 
Effect of zinc and nitrogen on onion

individual bulbs (Table $2 \mathrm{a}$ and $\mathrm{b}$ ). Total bulb yield was significantly higher in all treatments compared to control. The most effective treatments on bulb fresh weight and total yield were the spraying with 1 or $2 \mathrm{ppm}$ zinc and the application of $\mathrm{N}$ as $75 \%$ mineral and $25 \%$ organic, in both seasons.

\section{Bulb quality}

\section{Effect of Zn foliar application}

Application of $\mathrm{Zn}$ resulted in linear response of bulb diameter to the applied concentration (Tables $2 \mathrm{a} \& \mathrm{~b}$ and 3 ). However, difference between 2 and 3ppm Zn application was not significant. The effect of $\mathrm{Zn}$ application on neck thickness was clear with 2 and 3 ppm Zn concentration treatments where it was significantly reduced (Tables 2,3). Dry matter content of bulbs was increased significantly with 1 and $2 \mathrm{ppm} \mathrm{Zn}$ applications however 3 ppm did not differ significantly than the control.

\section{Effect of poultry manure}

Diameter of bulbs and neck thickness responded positively and significantly to the application of poultry manure treatments (Tables $2 \mathrm{a}$ and b). Similarly, poultry manure applications increased linearly the dry matter content of the bulbs (Table 3 ).

\section{Effect of interaction}

There was a positive response of bulb diameter to both factors where this character increased as both factors increased (Tables $2 a$ and $b$ ). The foliar spray of $\mathrm{Zn}$ at $3.0 \mathrm{ppm}$ along with the application of $\mathrm{N}$ as $75 \%$ mineral and $25 \%$ organic was the best treatment in both seasons.

Bulb neck thickness showed a significant difference compared to control treatment where all treatments resulted in smaller neck thickness. All combination of treatments significantly increased dry matter content compared to control with exception of 3 ppm $\mathrm{Zn}$ with null poultry manure treatment.

\section{Mineral content}

\section{Effect of $\mathrm{Zn}$ foliar application}

Nitrogen and $\mathrm{Zn}$ contents in the leaves was significantly affected by $\mathrm{Zn}$ foliar applications, total $\mathrm{Zn}$ content showed a clear positive and significant response to these treatments (Tables 2a and b).

\section{Effect of poultry manure}

Nitrogen and $\mathrm{Zn}$ contents in the leaves responded positively and linearly to the application of poultry manure treatments with all differences between treatments being significant (Tables 2 and 3 ).

\section{Effect of interaction}

Nitrogen content in the leaves was significantly influenced by the interactive effect of the treatments (Table 2a and b). Only treatments with null poultry manure application associated with all $\mathrm{Zn}$ applications were not significantly different than control. Meanwhile there was a clear increment in the concentration of $\mathrm{Zn}$ in the leaves as the rate addition of $\mathrm{Zn}$ application and poultry manure was increased. 
Abdel-Mawgoud; Abou-Hussein; Salman and Nemr

\section{DISCUSSION}

The aim of this study was to

contribute to the optimization of onion

crop growth and production by improving

root zone environment (addition of

organic matter) with possible interaction

with shoot environment ( $\mathrm{Zn}$ foliar

application). Zinc is one of the most

limiting trace element in agriculture and

deficiencies are common in alkaline and sandy soils (Sliman et al 1999). Zinc is required for photosynthesis (Sasaki et al 1998) and hence root and shoot growth. This may explain the increment in the number of leaves associated with $\mathrm{Zn}$ foliar application in this study. The same result was previously reported by Singh \& Tiwari (1995) and Meena \& Singh (1998) where foliar application of $\mathrm{Zn}$ had a positive effect on all plant vegetative growth. This effect may come from the fact that 
Effect of zinc and nitrogen on onion

Arab Univ. J. Agric. Sci., 13(3), 2005 
Abdel-Mawgoud; Abou-Hussein; Salman and Nemr

Arab Univ. J. Agric. Sci., 13(3), 2005 
Effect of zinc and nitrogen on onion

Arab Univ. J. Agric. Sci., 13(3), 2005 
$\mathrm{Zn}$ is involved in so many plant enzymes specially those in the photosynthesis process (Sasaki et al 1998), which means that deficiency greatly affects DM production (Joiner, 1983; Jones, 1983; Resh, 1983; Bergman, 1985 and Kumar et al 2000). Zinc is also essential for bulb formation, therefore early application is important. If zinc is low when bulbs are forming, yields will be significantly reduced (Kumar et al 2000). There was a positive relation between bulb yield and Zn foliar application in this study, which is in harmony with the findings of Meena \& Singh (1998) and Sliman et al (1999).

With the same number of plants per unit area, improvement in yield must have come from the improvement in individual plant yield. This is what has been observed in this study due to $\mathrm{Zn}$ application. Therefore bulb quality in terms of average individual fresh weight was improved by $\mathrm{Zn}$ application due to improvement in photosynthesis (Sasaki et al 1998). This has been observed before as a result of applying Zn (Pena et al 1999) and poultry manure (Gupta et al 1999 and Abbey, 2000).

Soil organic matter content may help in improving the availability of micronutrient, including $\mathrm{Zn}$, by forming complexes with them (Tagwira et al 1992). Moreover, occasional manure applications will supply the zinc needs for plants (Whiting et al 2002). It must be also noted that the amount of $\mathrm{Zn}$ in the poultry manure as revealed by the chemical analysis (Table $1 \mathrm{~b}$ ) may have contributed to the observed growth effects in this study.

Poultry manure has organic-N, which is being slowly recycled by a process called mineralization, back into plant available N (Lampkin, 1990). This resulted in increment in plant growth parameters such as plant length and number of leaves, which showed a linear correlation with the amount of poultry manure added in this study. This has been previously reported as a result of adding poultry manure to onion crop (Gupta et al 1999).

Increment in vegetative growth in current study may be due to increment in water availability in the soil, which may be brought about by increasing organic matter content. Increasing leaf number and length of the plant means increasing leaf area of the plant that intercepts light. This means higher rate of photosynthesis and production of assimilates. Higher water availability and assimilate production means higher fresh and dry weights of the leaves and that what have been observed in this study. Kumar et al (1998 and 2000) found that yield of onion was positively correlated with plant length, number of leaves per plant, fresh weight of leaves per plant and this is in harmony with our results.

The observed high $\mathrm{Zn}$ content in the leaves can be explained on the basis that all sprayed $\mathrm{Zn}$ salt was not completely absorbed and translocated to different plant parts. This is supported by the findings of Ferrandon and Chamel (1988) who mentioned that $\mathrm{Zn}$ applied either in chelated or in the sulfate-salt form, an extensive fixation by cuticle occurred at the point of application. They added that foliar absorption of this element was lower from chelates than from the inorganic salt, but the translocation within the plant was greater when chelated forms were applied.

Sliman et al (1999) mentioned that foliar spray treatments of $\mathrm{ZnSO} 4$ increased $\mathrm{Zn}$ 
concentration to its highest concentration and content.

\section{CONCLUSION}

It could be concluded that under experimental conditions, substituting part of the nitrogen mineral fertilizer with equivalent organic fertilizer along with $\mathrm{Zn}$ foliar application can improve onion crop production and quality. This will contribute to environmental saving by reducing the application of mineral $\mathrm{N}$ fertilizer hence reducing the fraction of these fertilizer that being leached to the under ground water.

\section{REFERENCES}

Abbey, L. (2000). Effect of poultry manure and post-production application of fungicide on the shelf-life of onion cv. Bawku Red. Crop Research Hisar. 20 (1): 87-92.

Bergman, E.L. (1985). Nutrient Solution Culture of Plants. The Pennsylvania State University College of Agriculture, Extension Service Hort. Mimeo Series II:160. pp: 21.

Black, C.A. (1965). Methods of Soil Analysis. Part2. American Society of Agronomy, INC., Publisher, Madison, Wisconsin, USA.

Brouwer, H.M.; G.R. Stevens and J.G. Fletcher (1981). Differential varietal response to zinc foliar sprays in navy beans (Phaseolus vulgaris). Queensl. J. Agric. Anim. Sci. 38: 181-185.

Chapman, H.D. and P.F. Pratt (1961). Methods of Analysis for Soils, Plant and Water., Div. of Agric. Sci. University of California, Riverside, USA.

FAO Statistics. (2004). Production Yearbook 2003. Vol. 57" Rome, Italy
Ferrandon, M. and A.R. Chamel (1988). Cuticular retention foliar absorption and translocation of iron, manganese and zinc supplied in organic and inorganic form. J. Plant Nutr. 11: 247-264.

Giardini, L.; M. Borin and G. Gianquinto (1992). Effects of poultry manure and mineral fertilizers on the quality of crops. J. Agric. Sci. 118 (2): 215-221.

Gupta, U. C. (1991). Iron status of crops in Prince Edward Island and effect of soil $\mathrm{pH}$ on plant iron concentration. Can. $\boldsymbol{J}$. Soil Sci. 71: 197-202. Gupta, R.P.; V.P. Sharma D.K. Singh and K.J. Srivastava (1999). Effect of organic manures and inorganic fertilizers on growth, yield and quality of onion variety Agrifound Dark Red. Newsletter National Horticultural Res-earch and Development Foundation 19: (2-3) 7-11. Joiner, J.N. (1983). Nutrition and fertilization of ornamental greenhouse crops, J. Janick (ed.). In: Horticultural Reviews, 5, pp. 380-403. AVI Pub. Co., Inc. Westport, CT., USA.

Jones, J.B. (1983). A Guide for the Hydroponic and Soilless Culture Grower. p. 124, Timber Press, Beaverton Oregon.

Khan, A. and C.M. Weaver (1989). Pattern of zinc-65 incorporation into soybean seeds by root absorption, stem injection and foliar application. J. Agric. Food. Chem. (37): 855-860.

Kropisz, A. (1992). Organic fertilizers in all cases improved cropping, with the highest average yields. Annals-ofWarsaw-Agricultural-University. 16: 913.

Kumar, M.; P.S. Munsi; D.K. Das; T.K. Chattopadhyay and M. Kumar (1998). Effect of zinc and sulphur 
application on the yield and post harvest quality of onion (Allium cepa L.) under different methods of storage. $\boldsymbol{J}$.

Interacademicia., 2 (3): 158-163. Kumar, M.; D.K. Das and D.K. Kumar (2000). Effect of zinc and sulfur application on their availability in soil in relation to yield and nutrition of onion (Allium cepa L.). Madras-AgriculturalJournal.84 (7): 382-384.

Lampkin, N. (1990). Organic Farming. Farming Press Books and Video. p. 91. Wharfedale Road, Ipswich IPI 4LG, United Kingdom.

Meena, O.S. and D. Singh (1998). Effect of sulfur and zinc application on onion yield and sulfur and zinc uptake in three soil orders. J. Indian Society of Soil Sci. 46 (4):636-640.

Pena, C.; B. Anez and M. Davila, (1999). Response of the onion (Allium cepa L.) to the application of sulfur, magnesium, zinc and boron in an alkaline soil. Revista-Forestal-Venezolana 43 (2): 173-182.

Rehm,. G. and M. Schmitt, (2000). Zinc for crop production. Publication of Extension Service of University of Minnesota F0-00720-GO., USA. Resh, H.M. (1983). Hydroponics Food Production. $2^{\text {nd }}$ Ed. p 335. Woodbridge Press Publishing Co., Santa Barbara, CA. SAS Institute (1991). SAS / STAT Users Guide. Version 6. $4^{\text {th }}$ Ed. SAS Inst., Cary, $N C$.

Sasaki, H.; T. Hirose; Y. Watanabe and R. Ohsugi (1998). Carbonic Anhydrase Activity and $\mathrm{CO}_{2}$-Transfer Resistance in Zn-Deficient Rice Leaves. Plant Physiol. 118: 929-934
Singh, D.P. and R.S. Tiwari (1995). Effect of micronutrients on growth and yield of onion (Allium cepa L.) variety Pusa Red. Recent-Horticulture. 2 (2): 70-77.

Sliman, Z.T.; M.A. Abdelhakim and A.A. Omran (1999). Response of onion to foliar application of some micronutrients. Egyptian J. of Agric. Res. 77 (3): 983-993.

Sloan, D.R.; G. Kidder and R. D. Jacobs (1996). Poultry manure as a fertilizer. Series of the Animal Science Department, pp. 1-3, Florida Cooperative Extension Service, Institute of Food and Agricultural Sciences, University of Florida. USA.

Tagwira, F.; M. Piha and L. Mugwira, (1992). Effect of $\mathrm{pH}$, and phosphorus and organic matter contents on zinc availability and distribution in two Zimbabwean soils. Commun. Soil Sci. Plant Anal. 23: 1485-1500. Vinay, S.; R.K. Singh and V. Singh (1995). Response of onion (Allium cepa L.) to N, P, Zn and FYM. Annals of Agricultural Research. 16 (1): 79-81. Weaver, C.M. (1985). Intrinsic mineral labelling of edible plants, methods and uses. CRC Crit. Rev. Food Sci. Nutr.; Issue: 1: 75-101.

Whiting, D.; C. Wilson, and A. Card (2002). Plant Nutrition. pp 1-7.

Cooperative Extension. CMG Fact Sheet No. S31. Colorado State University. USA. 
Arab Univ. J. Agric. Sci., Ain Shams Univ., Cairo, 13(3), 863-875, 2005

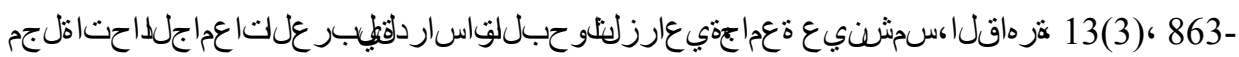
875 ، 2005

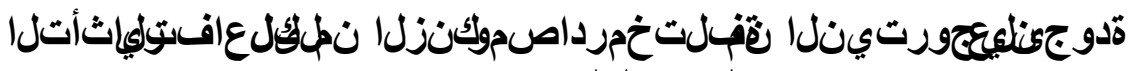

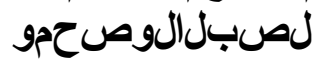

\section{|57|}

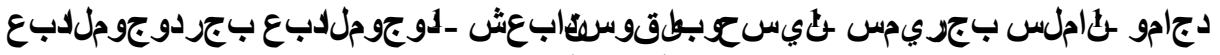

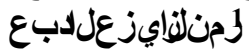

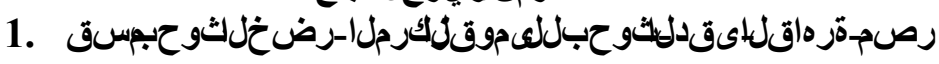

تبر تىفنفساردلا هذتير جأ

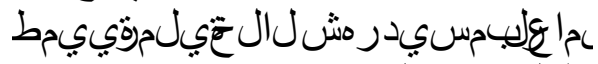

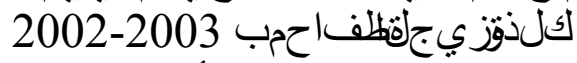

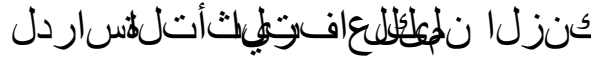

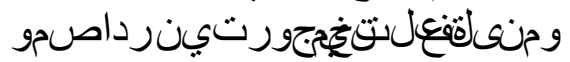

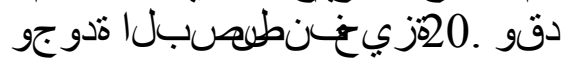

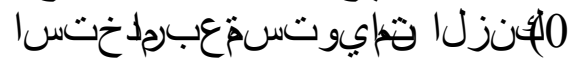

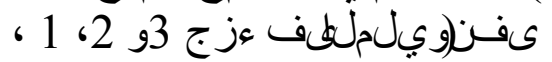

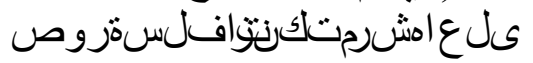

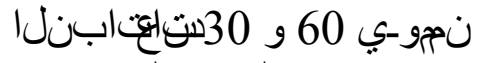

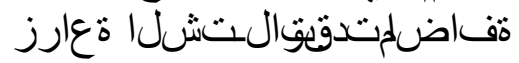

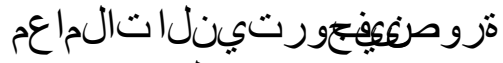

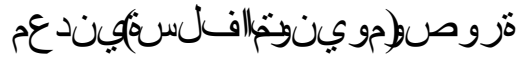

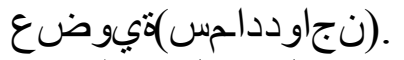
كندعم \% 100 1 و كوض

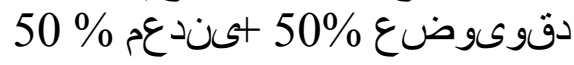

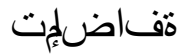

لالغنوض علدامسلثاليوتسجعيج

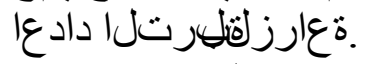

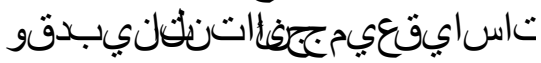

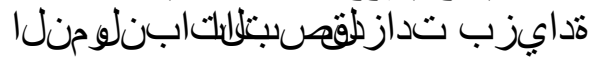

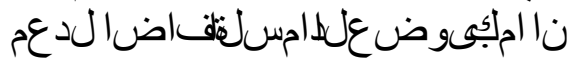

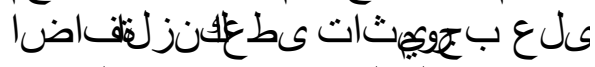
و تابنل

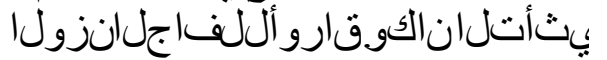

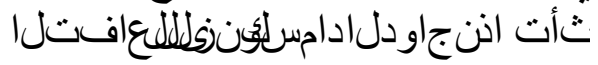
تدو جولوص اتنجلاةدايزىلكعباجيا

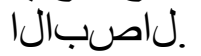

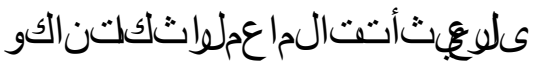

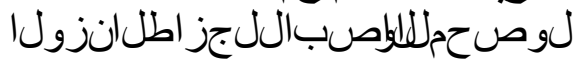
تاتابنلاتشر امدن عةدو جلهلهل كننفويلمليلف غز ج 2 ذيالكرتب

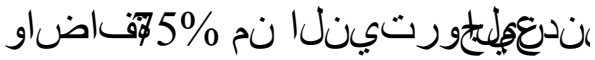

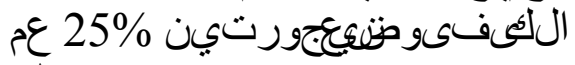

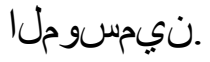

1- Vegetable Research Department, National Research Center, Dokki, Cairo, Egypt 
Arab Univ. J. Agric. Sci., Ain Shams Univ., Cairo, 13(3), 863-875, 2005

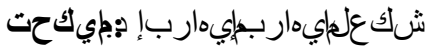

$$
\begin{aligned}
& \text { دي عسلنامث ع عيمس د. }
\end{aligned}
$$

1- Vegetable Research Department, National Research Center, Dokki, Cairo, Egypt (Received April 19, 2005) (Accepted May 16, 2005) 